\title{
PRINSIP-PRINSIP METODE PENDIDIKAN ISLAM DALAM ALQURAN
}

\author{
Fadriati \\ Program Studi Pendidikan Agama Islam, Jurusan Tarbiyah STAIN Batusangkar \\ Korespondensi: Perumahan Lika Alam Permai, No. 1 lima Kaum, Batusangkar, Tanah Datar \\ e-mail: fadriati@fad.yahoo.com
}

\begin{abstract}
In the first revelation, Allah has commanded man kind to read, to learn and to teach by means of media. By education, man has knowledge. Therefore, education must be carried out by means of effective methods to arrive at the expected goals. In thematic analysis, the Holy Quran in an-Nahl verse 125 points out three general principle method in Islamic teaching: al-hikmah, al-mau'izah al-hasanah and al-mujadalah. The Quran has demanded that education should be carried out on the basis of wisdom, humanism, and pluralism and full of tenderness and love.
\end{abstract}

Kata kunci: metode pendidikan Islam, al hikmah, al mau'izhah al hasanah, al mujadalah

\section{PENDAHULUAN}

$\mathrm{D}$ alam ayat yang pertama kali turun Allah SWT telah menyatakan bahwa pendidikan merupakan salah satu aspek yang penting dalam kehidupan Q.S. Al-Alaq 1-5 “ Bacalah (ya Muhammad) dengan nama Tuhanmu yang menciptakan. Bacalah dan Tuhanmu sangat pemurah. Yang mengajarkan dengan pena. Yang mengajarkan kepada manusia apa-apa yang tidak diketahuinya”.

Aspek yang terpenting dalam kehidupan manusia adalah pendidikan. Ayat di atas mengandung perintah membaca, mengajar dengan perantaraan media pena. Dengan pendidikan manusia mengetahui apa yang tidak pernah diketahuinya, dan dengan pendidikan pula manusia dapat membedakan antara yang baik dengan yang buruk.

Pelaksanakan pendidikan harus dengan mempergunakan metode-metode yang efektif untuk mencapai tujuan tersebut. Salah satu komponen yang terdapat dalam sistem pendidikan adalah metode pendidikan sebagai suatu cara penyampaian pelajaran kepada anak didik. Dalam Pendidikan Islam, metode yang dipakai dalam menyampaikan materi ajar kepada peserta didik harus sesuai dengan dasar dan sumber pendidikan Islam, yaitu Alquran dan Sunnah Rasullullah SAW.

Metode yang dikenal secara umum dalam dunia pendidikan adalah metode ceramah, tanya jawab, diskusi, eksperimen, pemberian tugas, demonsrasi, sosiodrama, kerja kelompok, simulasi, karya wisata dan lain-lain. Alquran banyak mengemukakan prinsip-prinsip metode Pendidikan Islam yang secara umum terdapat dalam firman Allah SWT QS Al-Nahl ayat 125 yang artinya "Serulah manusia ke jalan Tuhanmu dengan cara bijaksana dan pengajaran yang baik, serta berdebatlah dengan mereka secara baik pula. Sesungguhnya Tuhanmu lebih mengetahui orang- 
orang yang sesat dari jalannya dan orang-orang yang mendapat petunjuk".

Ada tiga prinsip umum metode Pendidikan Islam yang terdapat pada ayat di atas, yaitu: (1) Al-Hikmah, (2) AlMau'izah Al-Hasanah, dan (3) AlMujadalah. Alquran menuntut agar pendidikan dilaksanakan dengan penuh kebijaksanaan, menjunjung tinggi harkat kemanusian serta memperhatikan kemungkinan perbedaan peserta didik dengan penuh lemah lembut dan kasih sayang.

Penerapan metode pendidikan dilaksanakan secara bertahap, sebagaimana dikemukakan I.L. Pasaribu, yaitu" disesuaikan dengan tingkat kemampuan peserta didik, mulai dari yang mudah kepada yang sulit”. (Pasaribu, 1987: 43) Dalam pendidikan yang diterapkan di barat, "metode pendidikan hampir seluruhnya tergantung kepada kepentingan peserta didik, sedangkan guru hanya bertindak sebagai motivator dan stimulator". (Arifin, 1987: 76) Hal ini menyebabkan guru hanya bersikap mendorong dan merangsang peserta didik agar belajar, sedangkan pembentukan kepribadian kurang menjadi perhatian guru.

\section{PRINSIP-PRINSIP METODE PEN- DIDIKAN ISLAM DALAM AL- QURAN}

\section{Hakikat Metode Pendidikan Islam}

\section{Metode Pendidikan Islam}

Istilah metode berasal dari bahasa Yunani, yaitu metha dan hodos. Metha artinya melalui atau melewati, sedangkan hodos berarti jalan atau cara". (Arifin, 1987: 21) Jadi metode berarti arti jalan atau cara yang harus ditempuh atau dilalui untuk mencapai tujuan tertentu.

Secara umum metode juga diartikan sebagai cara mengerjakan se- suatu. Cara itu mungkin baik atau tidak baik, sebab baik tidak baiknya suatu metode tergantung kepada banyak faktor. Faktor tersebut dapat berupa situasi dan kondisi atau kurangnya pemahaman pemakai metode dalam mempergunakan metode yang ada. Jadi, metode adalah beberapa cara yang harus dikerjakan untuk mencapai tujuan-tujuan tertentu.

Metode pendidikan merupakan alat dan cara yang dipergunakan untuk mencapai tujuan pendidikan. Pendidikan sebagai suatu sistem, mempunyai beberapa prinsip dan komponen tertentu yang mendukung tercapainya tujuan Pendidikan Islam. Metode Pendidikan Islam adalah beberapa alat atau cara yang dipergunakan dalam proses Pendidikan Islam dalam upaya membentuk sikap dan kepribadian peserta didik berdasarkan prinsip-prinsip ajaran Islam. (Marimba, 1997: 45) Metode yang digunakan dalam proses pendidikan tersebut, juga harus disesuaikan dengan prinsip-prinsip dasar ajaran Islam yang terdapat dalam Alquran dan Hadis.

Tujuan mempergunakan suatu metode pendidikan adalah untuk memperoleh efektifitas dari metode tersebut. Efektifitas tersebut dapat diketahui dari adanya kemahiran pendidik di satu pihak dalam memakainya serta timbulnya minat dan perhatian dari peserta didik di pihak lain dalam pembelajaran. Oleh karena itu, semua aspek yang ada dalam kegiatan pendidikan perlu dikembangkan, baik dilihat dari sudut peserta didik, maupun dari pihak pendidik.

\section{Kedudukan Alquran dalam Pen- didikan Islam.}

\section{Pengertian Alquran}

Secara bahasa kata Alquran berasal dari kata qara-a yang berati "bacaaan". (Mahmud Yunus, 1957: 98) Sedangkan secara istilah Alquran adalah nama yang 
diberikan kepada firman Allah yang diturunkan-Nya kepada Nabi Muhammad SAW. dengan perantaraan malaikat Jibril untuk disampaikan kepada manusia yang dituliskan ke dalam mushaf, yang mutawatir penulikannya dan bersifat mukjizat bagi Nabi Muhammad, yang harus dibaca, dipahami dan diamalkan isinya oleh manusia agar tercapai kehidupan yang selamat dan bahagia dunia dan akhirat (Zaini: 1986: 1).

Alquran diturunkan Allah SWT adalah sebagai pedoman dan penuntun bagi manusia agar dapat mencapai keselamatan dan kebahagian hidup di dunia dan di akhirat, sebagaimana terdapat pada QS Al Maidah: 16. Oleh karena itu, Alquran berisi hal-hal pokok yang menyangkut segala aspek kehidupan manusia serta yang diperlukan untuk mewujudkan keselamatan dan kebahagian manusia tersebut.

Alquran berfungsi sebagai penjelas (al bayan), petunjuk (al huda), peringatan dan sebagai pembeda. Dalam hal ini Alquran berfungsi untuk memberikan penjelasan tentang metode pendidikan yang terdapat di dalam Alquran. Di dalam Alquran terkandung berbagai petunjuk untuk melaksanakan Pendidikan Islam yang sesuai pandangan Islam, di antaranya adalah prinsipprinsip metode Pendidikan Islam yang sesuai dengan ajaran Islam tersebut.

\section{Alquran sebagai Dasar Pendidikan Islam}

Dasar adalah tempat berdiri atau berpijaknya sesuatu, yang berfungsi memberikan arah kepada tujuan yang akan dicapai. Dasar inilah yang akan menjadi pedoman dalam merumuskan tujuan, termasuk dalam bidang pendidikan. Setiap negara mempunyai dasar pendidikan sendiri sebagai pencerminan filsafat hidup suatu bangsa. Demikian juga pendidikan dalam suatu negara harus berpedoman kepada dasar pendidikan dalam negara tersebut.

Dasar pendidikan Islam merupakan pencerminan filsafat hidup umat Islam yang didasarkan pada prinsipprinsip ajaran Islam yang terdapat dalam Alquran dan sunah Rasulullah SAW. Tujuan Pendidikan Islam juga harus diarahkan kepada dasar tersebut, karena dasar tersebutlah yang menjadi pedoman untuk menentukan arah dan tujuan Pendidikan Islam.

Pendidikan Islam memiliki sistem pendidikan sendiri yang berbeda dengan sistem pendidikan lain. Pendidikan Islam adalah pendidikan yang didasarkan kepada ajaran Islam, yaitu usaha yang dilakukan secara sadar berupa bimbingan, asuhan dan didikan terhadap peserta didik agar dapat memahami, menghayati dan mengamalkan ajaran-ajaran Islam sebagai bagian dari kebutuhan hidupnya.

Pendidikan Islam adalah "suatu bimbingan jasmani dan rohani berdasarkan hukum-hukum agama Islam menuju kepada terbentuknya kepribadian utama menurut prinsip-prinsip Islam" (Marimba,1987: 19)

Dasar Pendidikan Islam harus didasarkan pula kepada pandangan hidup umat Islam, yaitu prinsip-prinsip ajaran yang terdapat dalam Alquran dan sunah Rasulullah SAW. sehingga dapat pula dikatakan bahwa dasar Pendidikan Islam adalah selaras dengan dasar yang ada dalam ajaran Islam tersebut. Dasar pendidikan tersebut adalah (1) Alquran, (2) Hadis , (3) sikap dan perbuatan para sahabat, dan (4) Ijtihad ( Bawani: 1987: 17)

Kedudukan Alquran sebagai dasar dan sumber pokok Pendidikan Islam dapat dipahami dari ayat Alquran itu sendiri. Sebagaimana firman Allah SWT QS Al-A'raf: 52 “dan sesungguhnya kami benar-benar telah mendatangkan kepada mereka sebuah kitab, Kami telah menjelaskan atas dasar pengetahuan 
Kami; ia menjadi petunjuk dan rahmat bagi orang-orang yang beriman.

Menurut tafsir Al-Mishbah ayat ini berisi tentang penjelasan. Penjelasan itu adalah atas dasar pengetahuan yang sangat luas, mantap, dan menyeluruh, sehingga tidak ada kekurangan atau kelemahannya. Dengan demikian kitab ini benar-benar memberi petunjuk bagi siapapun yang ingin mendapat petunjuk dan rahmat bagi mereka yang menyambutnya, yaitu orang-orang yang beriman. (Shihab, vol 5, $2002: 65$ )

Ayat tersebut menjelaskan bahwa Alquran diturunkan oleh Allah SWT, adalah berisi ilmu pengetahuan yang banyak dan bermanfaat bagi umat manusia serta menjadi petunjuk bagi umat Islam untuk membedakan antara kebaikan dan keburukan.

Keseluruhan aspek kehidupan umat Islam harus berpedoman kepada Alquran, karena Alquran adalah pandangan hidup umat Islam. Dengan demikian, keseluruhan aspek dan aktivitas Pendikan Islam harus didasarkan pula kepada Alquran.

Dalam pelaksanaan Pendidikan Islam, keseluruhan teori dan praktek Pendidikan Islam tidak boleh bertentangan dengan ajaran-ajaran yang terdapat dalam Alquran. Seseorang tidak dapat berbicara tentang Pendidikan Islam apabila tidak mengambil Alquran sebagai dasar dan rujukannya.

\section{Prinsip Metode Pendidikan Islam dalam Alquran}

\section{Metode Ceramah dan Cerita}

Metode ceramah adalah "suatu cara penyajian atau penyampaian bahan pelajaran melalui penerangan dan penuturan secara lisan oleh guru terhadap anak didiknya. Dalam memperjelas penuturannya atau penyajiannya, guru dapat mempergunakan alat bantu, seperti benda, gambar, angket, peta, dan sebagainya". (Latief, 1985: 16)

Metode ceramah dalam Pendidikan Islam sudah dikenal sejak zaman Nabi Muhammad SAW. Dalam penyampaian pelajarannya, beliau banyak mempergunakan metode ceramah dari pada metode lain. Metode ini biasanya sejalan dengan metode cerita, yaitu penyampaian bahan pelajaran dengan menguraikan kembali cerita atau kisah-kisah sejarah yang mengandung hikmah dengan tujuan untuk memantapkan pelajaran yang disampaikan kepada peserta didiknya.

Dalam Pendidikan Islam,"cerita tentang kejadian, terutama tentang peristiwa sejarah, merupakan metode yang banyak ditemukan dalam Alquran". (Saleh, 1990: 206). Banyak ayat Alquran yang berisi kisah-kisah kesejarahan atau peristiwa yang pernah terjadi. Di samping itu banyak pula kisah-kisah sejarah yang diabadikan dalam namanama Alquran, misalnya Ali Imran, AlMaidah, Yunus, Hud, Al-Kahfi dan sebagainya. Dalam Alquran juga diceritakan makhluk bukan manusia, seperti jin dan malaikat.

Dalam memilih dan melaksanakan metode pendidikan, guru harus selalu memperhatikan tujuan pendidikan yang hendak dicapai. Dalam pendidikan Islam metode yang dipergunakan oleh guru harus selalu mengacu kepada pembentukan akhlak dan kepribadian yang mulia pada peserta didik sesuai dengan petunjuk Alquran dan Sunah Rasulullah SAW.

Dalam Alquran banyak ditemukan ayat yang menjadi prinsip pelaksanaan metode ceramah dan cerita, di antaranya adalah firman Allah QS Yusuf ayat 2-3 “ Sesungguhnya Kami menurunkan Alquran dengan berbahasa Arab, mudah-mudahan kamu memikirkannya. Kami ceritakan kepadamu sebaikbaiknya cerita dengan perantaraan 
Alquran yang Kami wahyukan kepada$m u$, sesungguhnya engkau dahulu termasuk orang-orang yang tidak mengetahui. ( QS. 12 :2-3)

Alquran juga mengakui bahwa metode ceramah dan cerita sangat baik dan penting dalam menyampaikan pelajaran agama Islam serta dalam mengajak manusia kepada jalan kebaikan. Prinsip yang lebih penting dalam melaksanakan metode ceramah dan cerita ini terdapat dalam Alquran QS An-Nahl: 125. Selain itu masih banyak ayat Alquran yang menjadi prinsip metode ceramah dalam pendidikan Islam. Di antaranya adalah firman Allah SWT dalam QS Al-A'raf: 176 “Apabila Kami kehendaki, niscya Kami tinggalkan dia dengan ayat-ayat kami, tetapi ia ingin tetap di bumi dan mengikuti hawa nafsunya. Maka umpamanya seekor anjing apabila mereka halau, dijulurkan lidahnya, atau mereka biarkan saja, diulurkan juga lidahnya, demikian itu adalah perumpamaan kaum yang mendustakan ayat-ayat Allah, oleh karena itu ceritakannlah kisah-kisah kesejahteraan itu agar mereka berfikir. (QS.Al A'raf/ 7: 176)

Menurut tafsir Al-Mishbah ayat di atas menguraikan keadaaan siapapun yang melepaskan diri dari pengetahuan yang telah dimilikinya. Allah Swt menyatakan kalau sekiranya Kami menghendaki, pasti Kami mensucikannya jiwanya dan meninggikan derajat dengannya. Orang yang menurutkan hawa nafsunya perumpamaannya adalah seperti anjing yang selalu menjulurkan lidahnya dan jika dibiarkannya, yakni tidak menghalaunya ia tetap menjulurkan lidahnya pula. Maka ceritakanlah kepada mereka dan siapapun kisah-kisah itu agar mereka berfikir, sehingga tidak melakukan hal ini. Amat buruklah perumpamaan orang-orang yang mendustakan ayat-ayat Allah, karena mengabaikan tuntunan pengetahuannya bahkan berbuat zalim terhadap diri mereka sendirilah bukan terhadap orang lain. (Shihab, vol 5, 2002: 303)

Kebaikan metode ceramah yang divariasikan dengan memberikan cerita atau kisah-kisah sejarah yang ada dalam Alquran akan dapat menarik minat dan perhatian peserta didik terhadap pelajaran yang disampaikan guru. Di samping itu metode ceramah dan cerita sangat bermanfaat untuk menyampaikan informasi dan pelajaran terhadap peserta didik.

\section{Metode Diskusi}

Metode diskusi dalam Pendidikan Islam adalah suatu cara penyajian atau penyampaian bahan pelajaran, di mana guru memberikan kesempatan kepada peserta didik atau kelompok untuk mengadakan pembicaraaan ilmiah guna mengumpulkan pendapat, membuat kesimpulan atau menyusun berbagai alternatif pemecahan suatu masalah. (Maimuddin, 1980: 47)

Metode diskusi sangat baik dipakai dalam pembelajaran, karena dalam metode diskusi dapat diselesaikan berbagai masalah yang berhubungan dengan bahan pelajaran yang akan diajarkan oleh guru. Metode diskusi juga memberikan kesempatan berfikir atau mengeluarkan pendapat bagi peserta didik serta dalam mencari penyelesaian yang sebaik-baiknya dari suatu permasalahan yang ada.

Di dalam Alquran juga banyak terdapat prinsip metode diskusi di antaranya adalah firman Allah terdapat dalam Alquaran surat An-Nahl, ayat 125 "Serulah manusia ke jalan tuhanmu dengan kebijaksanaan dan pengajaran yang baik, serta berdebatlah dengan mereka secara baik pula. sesungguhnya Tuhanmu lebih mengetahui orang-orang yang sesat dari jalan-Nya dan orangorang yang mendapat petunjuk.(QS An Nahl/16: 125) 
Ayat tersebut mengindikasikan bahwa metode diskusi (al mujadalah) diakui sebagai salah satu satu cara untuk dapat mengajak seseorang kepada jalan Allah SWT. Mujadalah yang maksud dalam ayat tersebut, bukan hanya sekedar berdebat dan berbantah-bantahan tentang suatu pendapat, namun lebih jauh dari itu untuk saling bertukar pikiran atau ide tentang suatu hal yang masih diragukan. Oleh karena itu, metode diskusi yang benar menurut prinsip Alquran tersebut adalah diskusi yang dilaksanakan dengan baik-baik dan bukan didasari atas kepentingan pribadi dan hawa nafsu.

Di dalam Alquran juga banyak contoh diskusi yang mengandung pelajaran, di antaranya terdapat dalam firman Allah SWT surat Al-Anbiya': 5256 "Ketika ia bertanya kepada bapak dan kaumnya: apakah patung-patung berhala ini selalu kamu sembah? Mereka berkata: kami dapati orang tua kami menyembahnya. Ibrahim berkata : sesungguhnya kamu dan orang tuamu dalam kesesatan yang nyata. Mereka berkata: adakah engkau mendatangkan kebenaran kepada kami atau engkau bermain-main? Dia berkata: bahkan tuhan kamu adalah tuhan langit dan bumi yang telah menciptakan semuanya. Dan aku menjadi saksi atas yang demikian. (QS. 21: 52-56)

Pada tafsir Al-Mishbah dijelas-kan bahwa patung atau berhala-berhala yang disembah oleh kaum nabi Ibrahim itu cukup banyak, tetapi yang terbesar mereka namai $b a ' l$. Patung ini terbuat dari emas yang melambangkan matahari. Nabi Ibrahim AS menyebutnya sebagai patung, bukan menamainya tuhan atau menyebutnya secara langsung. Hal ini menunjukkan bahwa sejak dini, beliau telah menegaskan sikapnya bahwa apa yang disembah oleh kaumnya adalah patung. Di samping itu, pertanyaan yang beliau ajukan itu merupakan kecaman terhadap sesembahan mereka serta kecaman terhadap sikap dan perilaku mereka yang demikian tekun menyembahnya (Shihab, vol 8, 2009: 75).

Abdurahman Saleh Abdullah mengemukakan bahwa pertanyaan atau dialog mempunyai beberapa tipe.Tipe atau pertanyaan dalam ayat tersebut adalah tipe atau pertanyaan untuk mengungkapkan atau mendefinisikan keimanan masyarakatnya (kaum nabi Ibrahim). Pertanyaan yang dilontarkan oleh umatnya kemudian dijawab oleh Nabi Ibrahim secara final dan mengacu kepada penemuan kebenaran. (Saleh, 1987: 213)

Kesimpulan yang diperoleh dari suatu diskusi akan sangat bermanfaat dalam memantapkan pelajaran yang diberikan kepada peserta didik. Pelajaran yang disampaikan dengan metode diskusi akan mudah dipahami dan diingat oleh peserta didik. Namun dengan metode diskusi ini tidak semua murid dapat mencapai tujuan yang diharapkan secara baik, karena kesulitan murid juga berbeda dalam kegiatan diskusi. Pendidik Islam harus mampu memainkan peranannya dalam mengembangkan pendidikan dengan cara memilih materi yang sesuai dan menarik bagi peserta didik serta memberikan kesempatan yang sama kepada peserta didik dalam berdiskusi.

\section{Metode Tanya Jawab}

Metode tanya jawab adalah "suatu metode mengajar di mana guru mengajukan pertanyaan kepada murid tentang pelajaran atau bacaan yang telah mereka baca sambil memperhatikan proses berfikir di antara mereka". (Ramayulis, 1991: 121) Metode ini sudah lama dipakai dalam dunia pendidikan. Dalam Pendidikan Islam, metode ini juga sudah ada sejak zaman Nabi Muhammad 
SAW. dan tetap berkembang sampai sekarang.

Metode tanya jawab dapat membantu pengembangan proses berfikir peserta didik dan dengan mudah menilai dan mengawasi perkembangan berfikir anak dalam proses pembelajaran. Tanya jawab adakalanya berguna untuk menghilangkan keraguan seseorang tentang suatu hal atau berupa pengujian terhadap sesuatu. Bahkan adakalanya pertanyaan timbul dari ketidaktahuaan seseorang. Dalam hal ini seseorang guru harus arif dan paham ke mana arah dan tujuan pertayaan yang diajukan kepada peserta didik, atau maksud suatu pertanyaan yang diajukan oleh peserta didik. Jawaban yang diberikan guru hendaknya tidak terbatas pada jawaban ya atau tidak, namun lebih jauh dari itu hendaknya mampu mengembangkan daya berfikir dan analisa peserta didik terhadap suatu persoalan.

Di dalam Alquran juga banyak terdapat dialog dan tanya jawab tentang berbagai persoalan, baik dialog yang terjadi antara Allah dan Malaikat, atau dialog para nabi dan kaumnya. Salah satu contoh tanyajawab yang terdapat dalam Alquran adalah sebagaimana yang digariskan dalam firman Allah SWT surat Al-Baqarah/2:30 "Ingatlah ketika Tuhanmu berfirman kepada mailakat: sesungguhnya Aku akan menjadikan seorang khalifah di muka bumi (Adam). Maka jawab mereka: adakah patut engkau jadikan seseorang yang akan berbuat bencana dan menumpahkan darah di atas muka bumi. Sedangkan kami tasbih memuji Engkau dan mensucikan engkau? Allah berfirman : sesungguhnya Aku mengetahui apa-apa yang tidak kamu ketahui. (QS. 2 : 30)

Pada tafsir Al-Mishbah dijelaskan bahwa ayat ini berisi tentang penyampaian keputusan Allah kepada para malaikat tentang rencana-Nya men- ciptakan manusia di bumi. Penyampaian kepada mereka penting karena malaikat akan dibebani sekian tugas yang menyangkut manusia. Ada yang bertugas mencatat amal-amal manusia, ada yang betugas memeliharanya, ada yang membimbingnya dan sebagainya. Penyampaian itu juga kelak ketika di ketahui manusia akan mengantarnya bersyukur kepada Allah atas anugerah-Nya yang tersimpul dalam dialog Allah dengan para malaikat "sesungguhnya Aku akan menciptakan khalifah di dunia". Mendengar rencana tersebut, para malaikat bertanya tentang makna penciptaan tersebut. Mereka menduga bahwa khalifah ini akan merusak dan menumpahkan darah. Dugaan ini mungkin berdasarkan pengalaman mereka sebelum terciptanya manusia, di mana ada makhluk yang berlaku demikian atau bisa juga berdasarkan asumsi bahwa karena yang akan ditugaskan menjadi khalifah bukan malaikat, pasti makluk itu berbeda dengan mereka yang selalu bertasbih dan mensucikan Allah SWT.

Syaikh Muhammad Abduh yang dikenal beraliran rasional dan berupaya untuk membatasi sedapat mungkin wilayah suprarasional dari ajaran agama ketika menafsirkan ayat 10-11 surat $\mathrm{Al}$ infithar ia menegaskan bahwa "malaikat adalah makhluk-makhluk gaib yang tidak dapat diketahui hakikatnya, namun harus dipercaya wujudnya. Ketika menafsirkan ayat ini syaikh Muhammad Abduh, sebagaimana diuraikan oleh Rasyid Riha dalam tafsirannya alManar, mengemukakan satu pendapat kontroversial. Ulama Mesir itu berpendapat bahwa tidak mustahil, tidak juga ada keberatan akal atau agama untuk memahami apa yang dinamai oleh agama Malaikat, dinamai oleh orang lain hukum-hukum alam.

Ibn Asyur lebih lanjut menulis bahwa ayat ini dipahami oleh banyak 
mufasir semacam permintaan pendapat, sehingga ia merupakan pengajaran dalam bentuk penghormatan, serupa dengan keadaan seorang guru yang mengajar muridnya dalam bentuk tanya jawab, agar mereka membiasakan diri untuk melakukan dialog menyangkut aneka persoalan.

Dengan merujuk pendapat para mufasir Ibn Asyur mengemukakan pendapatnya bahwa intisyarah permintaan pendapat itu dijadikan demikian agar ia menjadi satu subtansi yang bersamaan dalam wujudnya dengan penciptaan manusia pertama. Agar ia menjadi bawaan dalam jiwa anak cucunya, karena situasi dan ide-ide yang menyertai wujud sesuatu dapat berbekas dan menyatu antara sesuatu yang wujud dan situasi tersebut (Shihab, vol 1, 2002: 171-175).

Dengan demikian pertanyaan yang diajukan oleh para Malaikat kepada Allah (adakah engkau hendak menciptakan makhluk yang selalu berbuat kerusakan di muka bumi?) merupakan respon para malaikat atas pemberitahuan Allah tentang akan diciptakannya khalifah di muka bumi, sebagaimana surat Al-Baqarah di atas.

Banyak contoh tanya jawab yang terdapat dalam Alquran. Hal ini membuktikan bahwa metode tanya jawab diakui kebaikannya sebagai suatu metode dalam pendidikan. Sedangkan prinsip metode tanya jawab dalam Alquran dapat dilihat pada QS An-Nahl ayat 25.

Selain itu Alquran menggunakan metode tanya jawab dengan hal yang indah, menarik dan memuaskan. Allah SWT. berfirman pada QS 27: 59-64. Ayat tersebut merupakan salah satu contoh metode pendidikan dalam Alquran dengan metode tanya jawab. Allah mengajarkan manusia tentang kebesaran-Nya dan kekuasaan-Nya. Supaya manusia tidak bersifat angkuh dalam hidupnya serta mensyukuri segala rahmat yang diberikan Allah, dan supaya manusia tidak mempersekutukan Allah dengan yang lain.

\section{Metode Praktek}

Metode praktek adalah suatu cara mengajar dengan mempraktekkan segala ilmu pengetahuan yang telah diajarkan oleh guru kepada peserta didik. Pembentukan akhlak dan pembinaan kepribadian seseorang tidaklah cukup dengan sekedar nasehat atau pelajaran yang diberikan secara lisan maupun tulisan.

Alquran mengajarkan kewajiban yang harus dilaksanakan oleh setiap umat Islam. Menurut Muhammad Fadhil Al-Jamaly, " kewajiban yang dibebankan atas setiap umat Islam merupakan sarana untuk mendidik manusia dan membimbingnya dalam usaha mencapai tujuan Pendidikan Islam". (Al Jamaly, 1986: 74) Oleh karena itu Alquran diturunkan dengan membawa kewajibankewajiban tersebut tidak lain adalah untuk terus mendidik manusia dan membina kepribadiannya.

Islam mengajarkan keimanan dan tauhid kepada manusia serta cara mensyukuri nikmat yang diberikan oleh Allah. Keimanan dan segala pengetahuan yang diberikan Allah tersebut harus diamalkan dalam kehidupan sehari-hari. Demikian juga tentang perintah salat yang digariskan Allah dalam Alquran, sebagaimana yang terdapat dalam firman Allah surat Al-Ankabut ayat 45 "Bacalah apa yang telah diwahyukan kepadamu, yaitu Al-kitab, dan didirikanlah salat. Seungguhnya salat itu mencegah dari perbuatan keji dan mungkar.( QS. 29 : 45)

Menurut tafsir Al-Mishbah ayat dia atas berisi penjelasan tentang pesan kepada Nabi Muhammad SAW, terutama kepada umatnya bahwa sesungguhnya salat yang yang dilaksanakan 
sesuai tuntunan Allah dan Rasulnya senantiasa melarang atau mencegah pelaku yang melaksanakan secara bersinambungan dari keterjurumusan dalam kekejian dan kemungkaran. Hal itu disebabkan karena subtansi salat adalah mengingat Allah. Siapa yang mengingat Allah dia terpelihara dari kedurhakaan, dosa dan ketidakwajaran dan sesungguhnya mengingat Allah, yakni salat adalah lebih besar keutamaannya dari ibadah-ibadah lain dan Allah mengetahui apa yang kamu sekalian senantiasa kerjakan baik maupun buruk.

Banyak pendapat ulama tentang pengaitan ayat ini dengan fenomena yang terlihat dalam masyarakat. Ada yang memahaminya dalam pengertian harfiah. Mereka berkata sebenarnya salat memang mencegah dari kekejian. Kalau masih ada yang melakukannya maka hendaklah diketahui bahwa kemungkaran yang dilakukan dapat lebih banyak daripada apa yang terlihat atau yang diketahui itu.

Thabathaba'i ketika menasirkan ayat ini menggarisbawahi bahwa perintah melaksanakan salat pada ayat ini dinyatakan sebabnya, yaitu karena "salat melarang/mencegah kemungkaran atau kekejian". Ini berarti salat adalah amal ibadah yang pelaksanaannya membuahkan sifat keruhanian dalam diri manusia yang menjadikannya tercegah dari perbuatan keji dan mungkar.

Ibn 'Asyur berpendapat bahwa kata tanha'/melarang lebih tepat dipahami dalam arti majazi', sehingga ayat ini mempersamakan apa yang dikandung oleh salat dengan "larangan", dan mempersamakan salat dengan segala kandungan dan subtansinya dengan seorang yang melarang salat, baik pada ucapan maupun pada gerakan-gerakannya, mengandung sekian banyak hal yang mengingatkan kepada Allah, sehingga salat merupakan pemberi ingat kepada yang salat. (Shihab, vol 10, 2002: 505-509)

Salat mendidik rohani dan akal manusia, sebab ia dapat menghubungkan manusia dengan Tuhan-Nya. Ia mendidik manusia berkemampuan keras dan mengendalikan hawa nafsu, serta senantiasa menjaga amanat dan menepati janji. Pendidikan salat harus diberikan dengan metode praktek. Sebagaimana Rasulullah SAW. memerintahkan mengerjakan salat sebagaimana beliau salat.

\section{Metode Peringatan dan Nasehat}

Islam mengajarkan agar umat Islam saling memberi peringatan dan nasehat satu sama lain. Hal ini diwajibkan dalam Islam mengingat pentingnya manfaat peringatan dan nasehat dalam menegakkan kebenaran dan kebaikan. Oleh karena itu pendidik Islam harus dapat berfungsi sebagai pemberi peringatan dan nasehat yang baik kepada peserta didik sesuai dengan ajaran Islam.

Mengajarkan kebaikan dengan memberikan nasehat serta mengajak orang lain melaksanakan kebaikan tersebut adalah termasuk metode pendidikan Islam. Sedangkan prinsp metode peringatan dan nasehat ini banyak terdapat di dalam Alquran. Di antaranya adalah firman Allah SWT dalam surat Az-Zariyat ayat 55 "Dan tetaplah memberi peringatan kepada orang lain supaya ia selalu ingat terhadap tugas dan kewajibannya sebagai hamba Allah.

Metode peringatan dan nasehat ini cukup penting dalam pendidikan Islam, sehingga ayat Alquran juga sering kali mengulang tentang pentingnya peringatan. Hal ini juga dapat dilihat dari firman Allah QS 88: 21 "maka berilah peringatan karena sesungguhnya kamu hanyalah orang yang memberi peringatan. (QS 88: 21)

Ayat tersebut menunjukkan bahwa Islam memandang setiap manusia adalah 
pendidik dan mampu menjadi pendidik dan mampu mempunyai kewajiban mengajak manusia lain kepada kebenaran dengan memberi peringatan kepada orang lain dengan kebaikan.

\section{Metode Ganjaran dan Hukuman}

Istilah ganjaran dalam Alquran menunjukkan apa yang diperbuat oleh seseorang dalam kehidupannya atau di akhirat kelak, karena amal perbuatannya yang baik. (Abdullah,1987:220). Sedangkan Ngalim Purwanto mengatakan bahwa ganjaran adalah alat untuk mendidik anak-anak supaya dapat merasa senang karena perbuatan atau pekerjaannya mendapat penghargaan. (Purwanto, 1989: 231)

Ganjaran adalah tindakan yang menyenangkan yang diberikan oleh pendidik yang mempunyai prestasi, kerajinan dan tingkah laku yang baik. Tindakan pendidik tersebut dapat menimbulkan keinginan anak lain untuk mencontohnya.

Sedangkan hukuman dalam pendidikan adalah tindakan yang dijatuhkan kepada peserta didik secara sadar dan sengaja, sehingga menimbulkan nestapa. Hal yang demikian membuat si anak menjadi sadar terhadap perbuatannya dan berjanji dalam hatinya tidak akan mengulangi perbuatannya yang salah. (Anshari, 1983: 69)

Hukuman dalam pendidikan merupakan tindakan terakhir yang diberikan kepada peserta didik setelah peringatan dan nasehat tidak mempan lagi untuk memperbaiki sikap dan tingkah laku peserta didik. Karena hukuman kadangkala dapat menimbulkan perasaan tidak senang dari peserta didik, bahkan dapat menimbulkan sikap perlawanan dari peserta didik.

Al-Ghazali mengemukakan penggunaan hukuman dan ganjaran sebagai metode Pendidikan Islam sebagaimana dikutip Fathiyah Hasan Sulaiman bahwa jika anak melakukan perbuatan yang baik dan akhlak yang terpuji, dan jika mungkin dengan memberinya hadiah yang baik, dipuji di depan orang-orang penting dan berkedudukan sebagai motivasi baginya. (Hasan Sulaiman,1986: 80)

Alquran sebagai dasar Pendidikan Islam juga banyak mengemukakan prinsip-prinsip ganjaran dan hukuman dalam Pendidikan Islam. Di antaranya terdapat dalam firman Allah QS : 6: 160 "Siapa yang datang dengan membawa satu kebaikan, maka baginya pahala sepuluh kali lipat. Dan siapa yang datang dengan membawa satu kejahatan, maka tiadalah ia dibatasi melainkan dengan yang seperti itu pula, sedangkan mereka itu tiada teraniaya. (QS: 6: 160)

Metode ganjaran dan hukuman dipergunakan sebagai salah satu cara untuk mendidik dan mencapai tujuan pendidikan Islam, yaitu membentuk manusia yang beriman kepada Allah, beramal shaleh, berakhlak baik dan mulia. Salah satu bentuk penggunaan ganjaran dalam pendidikan adalah memuji anak yang dapat menjawab pertanyaan guru dengan baik, maka anak tersebut akan merasa senang dan bergairah serta semakin bersemangat mengikuti pelajaran yang diberikan oleh guru. Contoh pemberian hukuman dalam Pendidikan Islam dapat dilihat dari hadis Nabi Muhammad SAW. "dari Amr bin syu'aib dari ayahnya, dari datuknya, ia berkata: Rasulullah SAW bersabda: suruhlah anak-anakmu mengerjakan salat pada usia tujuh tahun, dan pukulkah mereka apabila melalaikannya pada usia sepuluh tahun, pisahkanlah mereka dari tempat-tempat tidurmu. (HR. Abu Daud) (Authar, 1982: 282)

Hadis tersebut memberikan pemahaman bahwa hukuman termasuk metode dan alat Pendidikan Islam. Namun dalam memberikan ganjaran dan hukuman kepada peserta didik tidak 
boleh berlebihan, sehingga tidak sesuai lagi dengan maksud dan tujuan pendidikan Islam yang sebenarnya.

\section{PENUTUP}

Alquran memuat prinsip-prinsip metode ceramah dan metode cerita, metode tanya jawab, metode diskusi, metode praktek, metode pemberian

\section{DAFTAR RUJUKAN}

Abdullah, Aburahman Saleh. 1990. Teori-Teori Pendidikan Berdasarkan Alquran. Jakarta: Rineka Cipta.

Al-Jamali, Muhammad Fadhil. 1986. Filsafat Pendidikan dalam Alquran. Surabaya: Bina ilmu

Bolla, John I. 1985. Keterampilan Mengelola kelas. Jakarta: Dikti Depdikbud

Langgulung, Hasan. 1991. Pendidikan dan Peradaban Islam, Jakarta: Pustaka Al-Husna.

Latif, Ruslan. 1985. Cara Belajar Siswa Aktif. Padang: fakults Tarbiyan IAIN Iman Bonjol.

Marimba, Ahmad D. 1980. Pengantar Filsafat Pendidikan Islam. Bandung: Al-ma'arif.

Pasaribu, I.L. 1987. Proses Belajar Mengajar. Bandung: Transsito

Poerwanto, Ngalim. 1987. Ilmu Pendidikan Teoritis dan Praktis. Bandung: Remaja Karya.

Indeks

al hikmah

anak $1,85,88,89,91,92$

guru $83,85,86,87,88,89,92$

media 1 peringatan dan nasehat, metode ganjaran dan hukuman. Semua prinsip-prinsip metode yang terdapat di dalam Alquran tersebut dapat digunakan sebagai alat atau cara untuk mencapai tujuan Pendidikan Islam, yaitu terbentuknya akhlak mulia dan kepribadian utama yang Islami sesuai dengan Alquran dan sunah Rasulullah SAW.

Ramayulis, 1991. Metodologi Pengajaran Agama Islam. Jakarta: Kalam Mulia

Shihab, M. Quraish. 2002. Tafsir AlMishbah. Pesan, Kesan dan Keserasian Alquran. Vol 1, Jakarta: Lentera Hati, 2002 2002. Tafsir Al-Mishbah Pesan, Kesan dan Keserasian Alquran Vol 10 Jakarta: Lentera Hati 2002. Tafsir Al-Mishbah, Pesan, Kesan dan Keserasian Alquran. Vol 5. Jakarta: Lentera Hati.

.....2002. Tafsir Al-Mishbah. Pesan, Kesan dan Keserasian Alquran. Vol 8 Jakarta: Lentera Hati

Sulaiman, Fathiyah Hasan. 1986. Alam Fikiran Al-Ghazal., Bandung: diponogoro.

Yunus, Mahmud. 1957. Sejarah Pendidikan Islam. Jakarta: Mutiara.

metode $.1,83,84,85,86,87,88,89,90,91$, 92

pena. 1

pendidikan ...1, 83, 84, 85, 86, 88, 89, 91, 92 
Ta'dib, Volume 15, No. 1 (Juni 2012)

sistem

$1,83,84$ 